International Journal of Research in Advent Technology, Vol.7, No.5, May 2019

E-ISSN: 2321-9637

Available online at www.ijrat.org

\title{
Distribution Patterns of Acmella paniculata (Wall. Ex DC.) R. K. Jansen in Gujarat, India
}

\author{
Sveta Patel ${ }^{1 *}$, Sandip Gamit ${ }^{1}$, Umerfaruq Qureshimatva ${ }^{1}$ and Hitesh Solanki ${ }^{2 *}$ \\ ${ }^{1}$ Research scholar, Department of Botany, Bioinformatics and Climate change Impact Management, Gujarat \\ University, Ahmedabad-380009 \\ ${ }^{2}$ Professor, Department of Botany, Bioinformatics and Climate change Impact Management, Gujarat University, \\ Ahmedabad-380009 \\ *corresponding author: swetapatel93.sp@gmail.com and husolanki@yahoo.com
}

\begin{abstract}
Acmella paniculata (Wall. Ex DC.) R. K. Jansen commonly known as "Akarkara" or "toothache plant" is an important medicinal herb of Asteraceae occurring in the tropics and subtropical parts of the world. "Akarkara" is of great medicinal value because of a rich source of bioactive compound known as spilanthol. Due to this compound, the plant has immense application in pharmaceuticals, food, health and body care products. In India, the plants have been growing in the northern and southern hills and plateaus. It is distributed in Andhra Pradesh, Assam, Kerala, Karnataka, Megalaya, Madhya Pradesh, Rajasthan and Tamil Nadu. Present study deals with the distribution of Acmella paniculata (Wall. Ex DC.) R. K. Jansen in Gujarat state. In Gujarat, Acmella has been found in Sabarkantha, Banaskantha, Dahod, Panchmahal, Chota-udepur, Narmada, Bharuch, Surat, Tapi, Valsad, Navsari and Dangs. This study will give the clear idea about its habitat and distribution.
\end{abstract}

Keywords: Acmella paniculata, medicinal, distribution, habitat, Gujarat

\section{INTRODUCTION}

In 1760, Jacquin was first to describe Spilanthes with two species, Spilanthes incipida and S. urens. After that Richard in 1807 described Acmella as a genus of five species that differ from species of Spilanthes in having ray florets and lack of pappus. Cassini (1822) suggested that Acmella might be treated better as a section within Spilanthes. In 1836, De Candolle followed Cassini's suggestion and recognized two sections, namely sect. Salivaria DC. And sect. Acmella (Rich.) DC. Moore (1907) in his revision of the genus Spilanthes described section Salivaria, with 13 species and section Acmella, with 26 species. Jansen (1981) provided convincing evidences for the recognition of Acmella and Spilanthes as distinct genera based on morphological, chromosomal and molecular evidences. $\mathrm{He}$ characterized Spilanthes with stiff awned pappus, monomorphic achenes, sessile leaves, discoid heads and white to purplish-white corolla. On the other hands, Acmella consists of soft pappus bristles, dimorphic achenes, petiolate leaves, radiate and discard heads and usually orange-yellow to yellow or occasionally white corolla. Jansen (1985) transferred some of the taxa from Spilanthes to Acmella and finally recognized 30 species and 9 infraspecific taxa in Acmella (Reshmi et. al, 2016).

Acmella paniculata (Wall. Ex DC.) R. K. Jansen belongs to family Asteraceae. It is commonly known as "toothache plant" because of its wide use by tribals to cure toothache and gum inefctions. In Gujarati is known as 'Marethi', in Konkani and Marathi it is known as 'Akkalkaro' and in Nepali it is known as 'Laato ghans'. The genus Acmella (Spilanthes) has more than 30 species, generally occurring in the tropics and subtropical parts of the world (Reshmi et. al, 2016). It is native to the Bangladesh, Brazil, China, Colombia, Ecuador, India, Indonesia, Nepal, Papua, New Guinea, Peru, Solomon Islands, Sri Lanka, Taiwan, Province of China, Thailand and Viet Nam. In India, these species have been growing in the northern and southern hills and plateaus. In India, it is distributed in Andhra Pradesh, Assam, Chattisgarh, Goa, Gujarat, Himachal Pradesh, Kerala, Karnataka, Megalaya, Maharastra, Madhya Pradesh, Rajasthan 


\section{International Journal of Research in Advent Technology, Vol.7, No.5, May 2019 E-ISSN: 2321-9637 \\ Available online at www.ijrat.org}

and Tamil Nadu (Cook, 1996). Six species reported from the genus Acmella in India are, A. ciliata, A. oleracea, A. panicuata, A. radicans, A. ungulliosa and A. calva (efloraofindia, 2007 onwards).

\section{DESCRIPTION}

Acmella Persoon, Syn.P1 2:472. 1807

Herbs, annual or perennial. Leaves opposite and/or basally rosulate. Capitula solitary or in fewheaded cymes, radiate, disciform, or discoid. Involucres \pm hemispheric to ovoid; phyllaries 1-3seriate, subequal or with outer row spreading and longer, entire or irregularly dentate; receptacles conical; paleae falling with achene, \pm navicular, membranous to scarious, each \pm equaling subtended floret. Ray florets, when present, 2- or 3-lobed, variously colored. Disk florets: corolla yellow or orange, 4- or 5-lobed. Achene margin ciliate, glabrous, or sometimes corky; ray achenes broadly ovate or elliptic, 3-angled; disk achenes ellipsoid, strongly compressed; pappus absent or of up to 10 awnlike bristles.

Acmella paniculata (Wall. ex DC.) R.K.Jansen Syst. Bot. Monogr. 8671985.

Herbs, annual. Stems branched, erect or ascending, to $30 \mathrm{~cm}$ or more tall, rarely rooting at nodes. Petiole $1-2 \mathrm{~cm}$; leaf blade ovate to ovatelanceolate, $2-4 \times 1-2.5 \mathrm{~cm}, 3$-veined, base cuneate, margin entire or coarsely or crenately serrate, apex acute. Capitula discoid, solitary, terminal or axillary, 8.4-12.5 × 6.9-10 mm; peduncles $2.5-16 \mathrm{~cm}$, sparsely pilose; phyllaries 9-12, 2-seriate, ovate-lanceolate, ca. $6 \mathrm{~mm}$, herbaceous, glabrous; receptacle 5-8 $\times 1.1-3$ $\mathrm{mm}$, apex acuminate. Florets 90-200; corollas tubular, minute, 4- or 5-lobed. Achenes obovoid, 3angled, ca. $3 \mathrm{~mm}$, margin scabrid, apex slightly depressed; pappus of 2 subequal bristles, longer one 0.5-1.1 mm, shorter one 0.4-0.9 mm.

Flowering - fruiting: - October to April

\section{IMPORTANCE AND UTILIZATION}

Acmella paniculata has been utilized by tribes in all over the world. Because of its edible value it has been used as food by ancient time. Its leaves and flowers are edible. Fresh leaves are used in making salads. The leaves may also use to treat bacterial and fungal skin diseases. Flowers are used to cure tooth-ache and gum infections. Chewing the heads relieves toothache or a tincture made from the flower heads and applied in some lint to the teeth and gums is even more effective against toothache. In ancient time it has been used as medicine for treatment of many diseases like, rheumatism, cold and fever, purgation, urinary tract infection, pulverization of kidney, gall stones and remedy for stammering in children. Acmella is a great source of bioactive compound spilanthol. Due to this compound, the plant has immense application in pharmaceuticals, health and body care products.

\section{DISTRIBUTION IN GUJARAT}

Gujarat has divided into five biogeographical regions, namely South Gujarat, Central Gujarat, North Gujarat, Saurashtra and Kachchh. Acmella paniculata is commonly found from all the districts of South Gujarat namely Bharuch, Narmada, Surat, Tapi, Navsari, Valsad and Dangs. In Central Gujarat it is frequently seen from Dahod, Panchmahal and Chota-udepur districts. In North Gujarat it is reported from Sabarkantha and Banaskantha districts only. It is not reported from Saurashtra and Kachchh regions. Bhole and Pathak (1988) and Shah G.L. (1978) have reported Acmella from Junagadh and beyt dwarka region of Saurashtra but in recent study it is not found from these regions.

\section{HABITAT}

Acmella paniculata generally found along fresh water habitats like, Rivers, streams, lakes, ponds, marshes, swamps etc. It also found in harvested paddy fields, sugar cane fields and waste wetlands. It usually grows associated with some other species like, Acmella radicans, Polygonum glabrum, Alternanthera polygonoides, Alternanthera sessilis, Synedrella nodiflora, Cyperus spp., Scirpus spp., Ipomoea carnea, Blumea spp., Cythocline purpurea, Spearanthes indicus, Eclipta prostate, Marsilea sp., Hygrophilla schuli, Eragrostis spp., Ammania baccifera

etc. 
International Journal of Research in Advent Technology, Vol.7, No.5, May 2019

E-ISSN: 2321-9637

Available online at www.ijrat.org

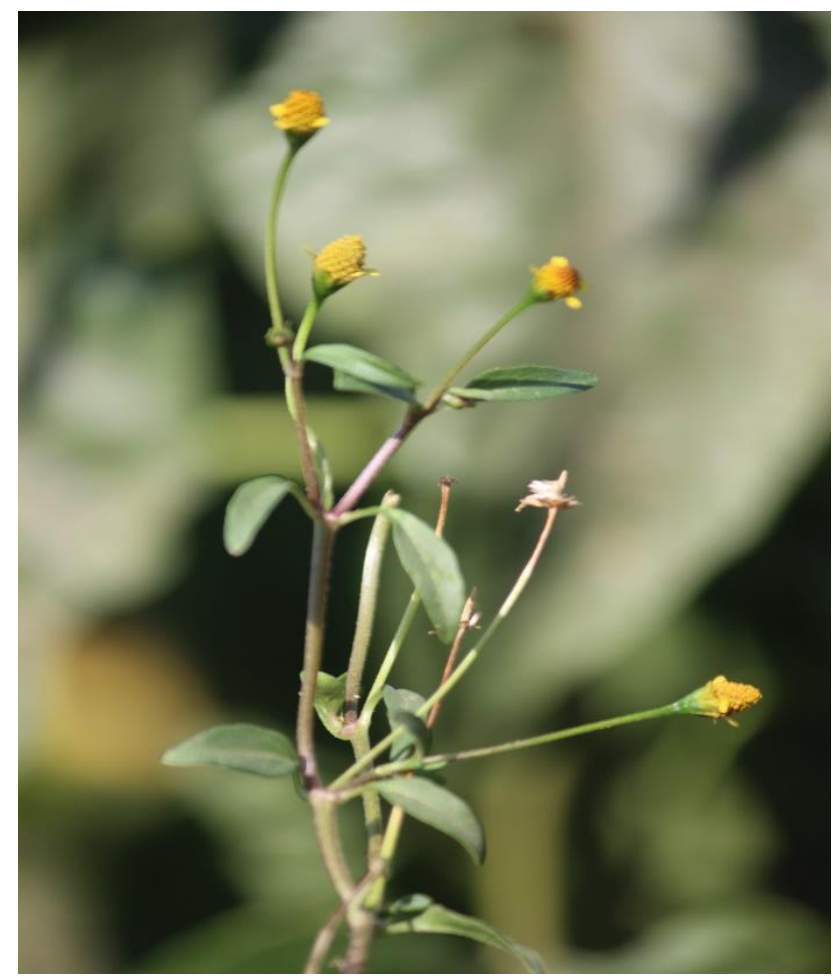

A. Whole young plant

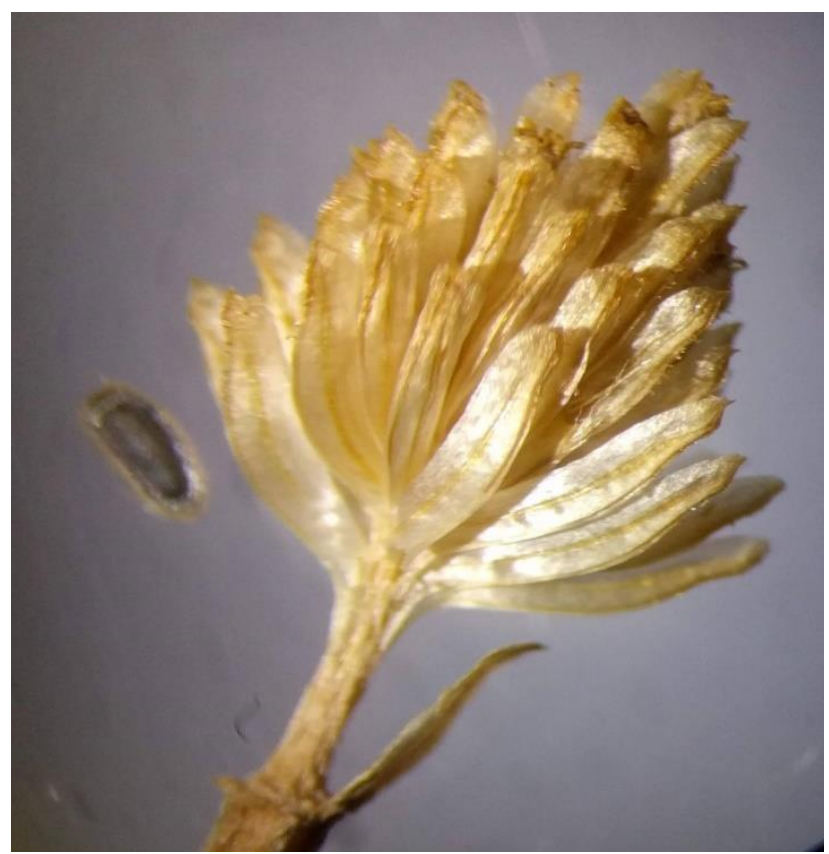

C. Dehisced flower

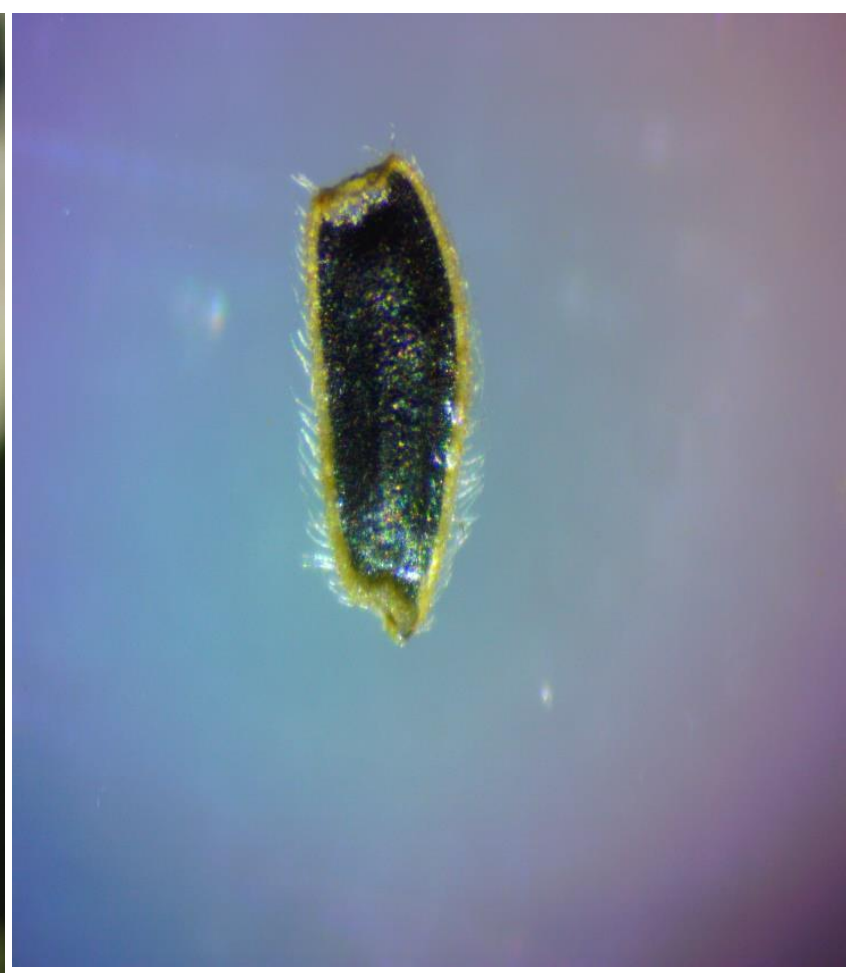

B. Achene

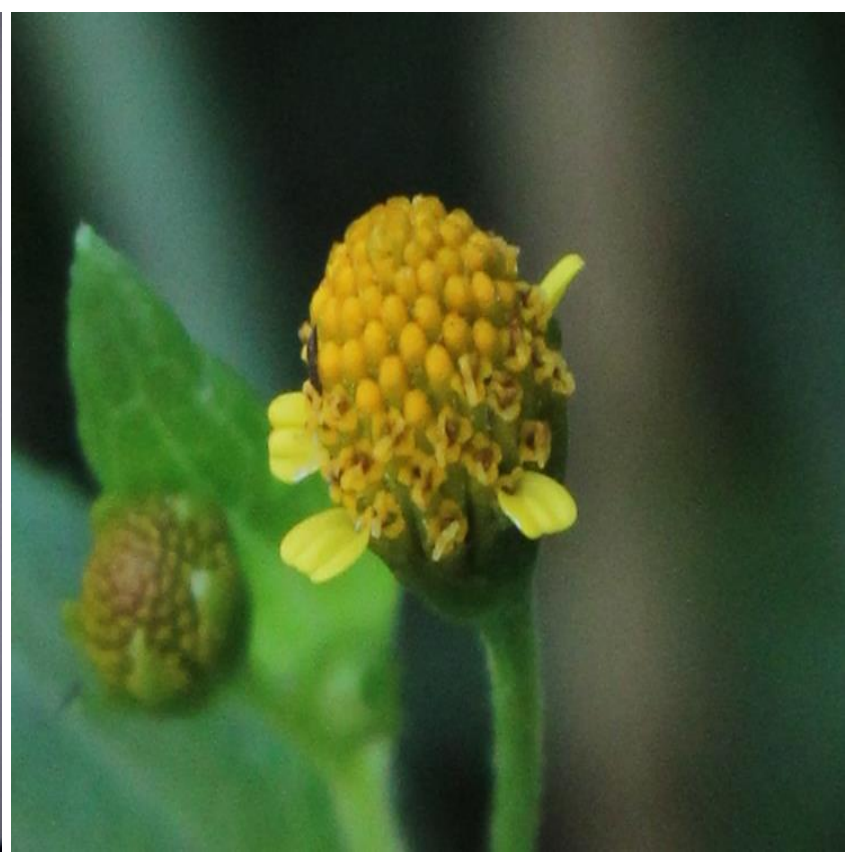

D. Flower

Fig: 1 Photographic images of Acmella paniculata (Wall. Ex DC.) R.K.Jansen 
International Journal of Research in Advent Technology, Vol.7, No.5, May 2019

E-ISSN: 2321-9637

Available online at www.ijrat.org

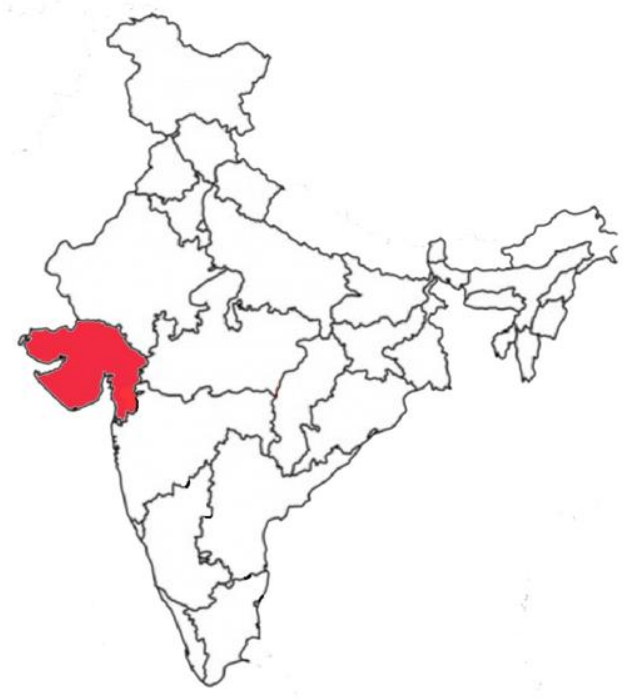

INDIA

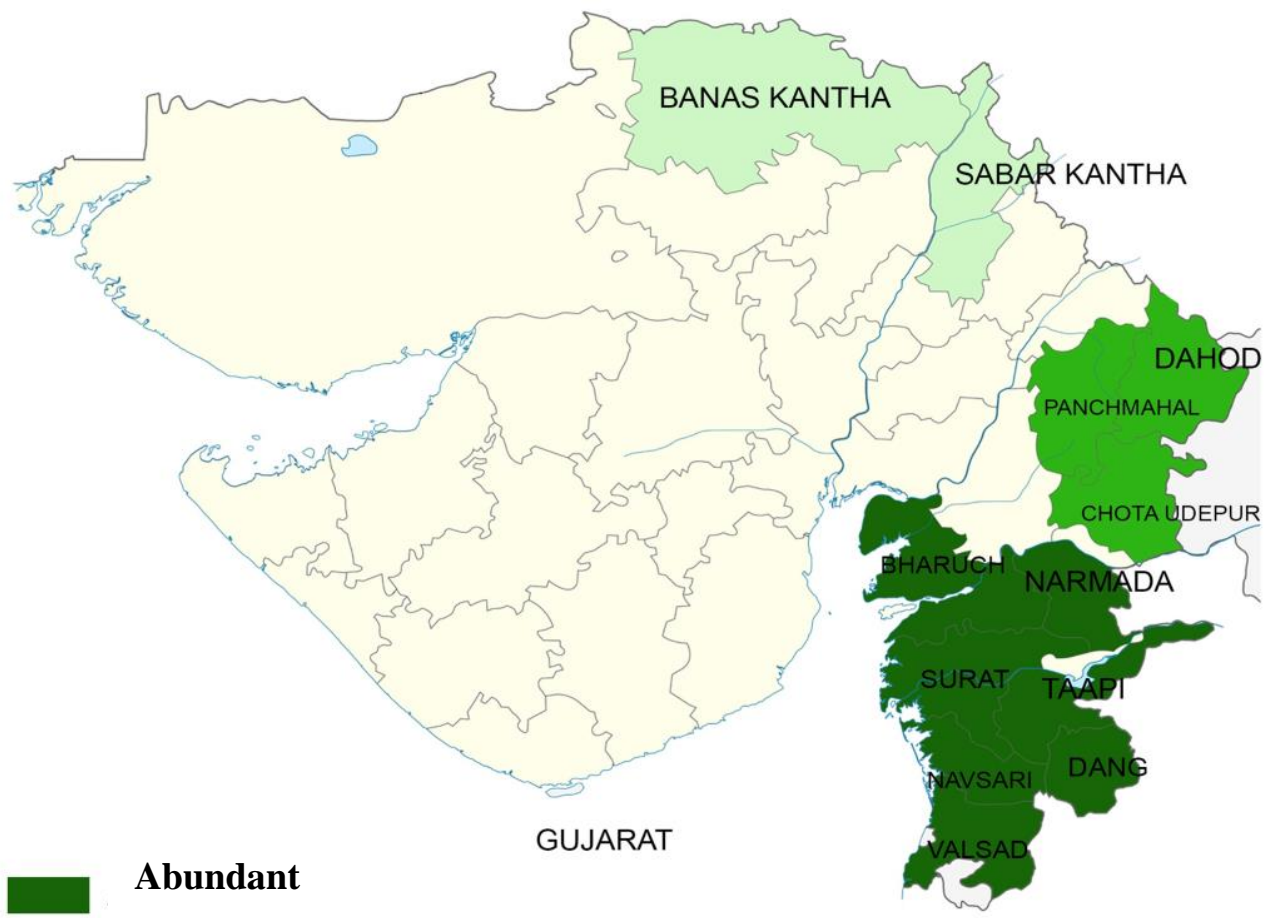

Frequent

Occasional

Fig: 2 Map showing distribution of Acmella paniculata (Wall. Ex DC.) R.K.Jansen in Gujarat, India 

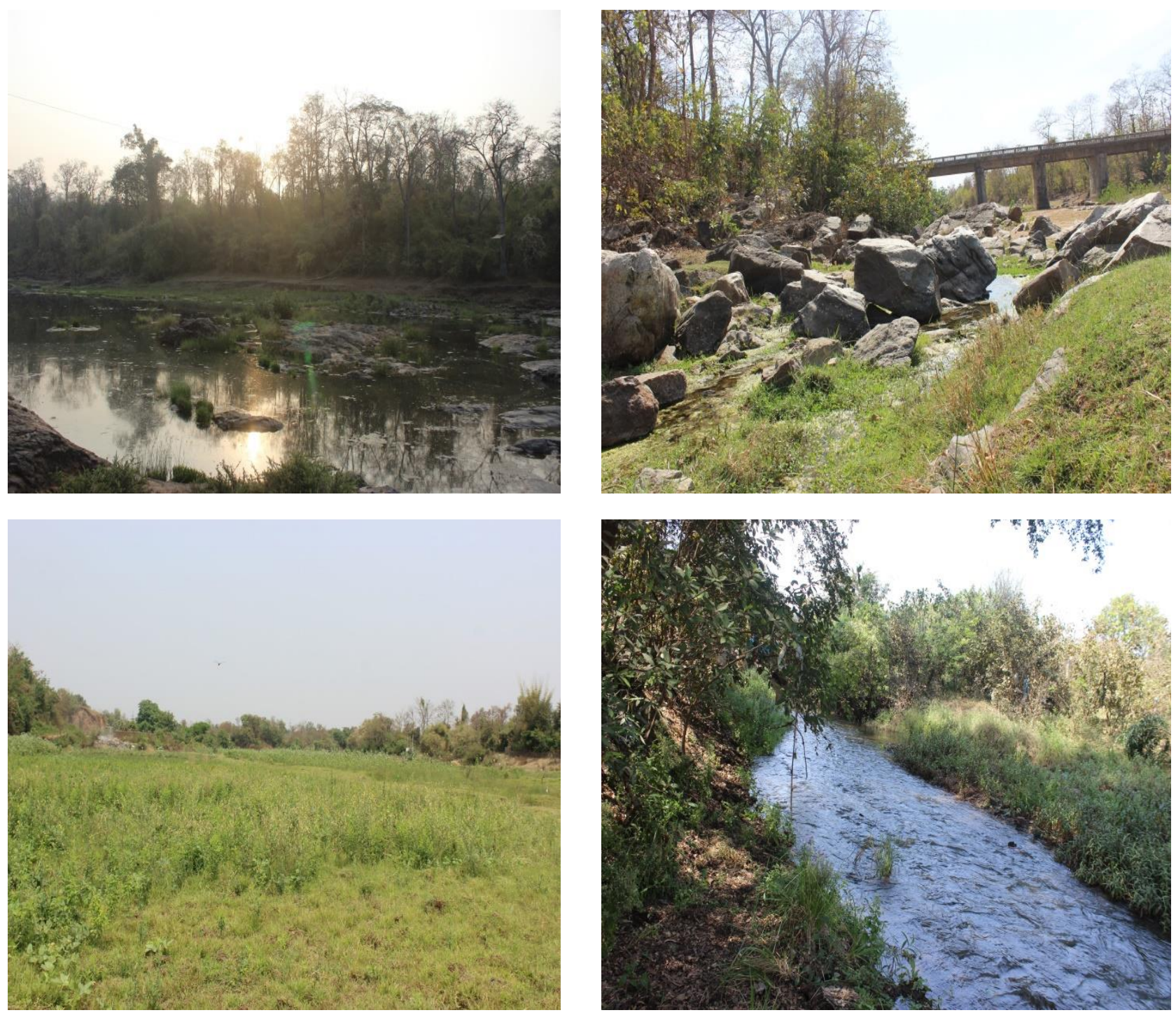

Fig: 3 Different habitats of Acmella paniculata (Wall. Ex DC.) R.K.Jansen

\section{CONCLUSION}

Acmella paniculata found abundantly in all districts of South Gujarat because of its favorable habitat and optimum rainfall. It is moderately distributed in districts of central Gujarat. In Central Gujarat it is reported from Banaskantha and Sabarkantha. It is not found in Saurastra region because of its dry and scrubby habitat. It is also not found in Kuchchh because of high levels of salinity in the soil. Present study concludes that the distribution pattern of Acmella paniculata strongly relies on habitat, soil, and rainfall.

\section{ACKNOWLEDGMENT}

The authors are thankful to the Department of Botany, Bioinformatics and Climate change Impact Management, Gujarat University, Ahmedabad, for providing the required infrastructural facilities and University Grants Commission Info Net and INFLIBNET, Gujarat University for providing resource facilities. 


\section{REFERENCES}

[1] Cassini, H. (1822) Spilanthes. In: Cassini H (Ed) Dictionorie des sciences naturelles. Le Normant, Paris. pp. 328-331.

[2] Cook, C.D.K. (1996) Aquatic and Wetland Plants of India. Oxford University Press, Oxford.; IUCN. 2011. IUCN Red List of Threatened Species (ver. 2011.1).

[3] De Candolle, A.P. (1836) Spilanthes. In: DeCandolle AP (Ed) Prodromus systematis naturalis regni vegetables.Treuttel and Wurtz, Paris, pp. 620-626.

[4] Efloraofindia (2007 onwards). Database of Indian Plants - developed by the members of the Efloraofindia Google group. Accessed at https://sites.google.com/site/efloraofindia/ on [25 July 2016 (replace with current date)]."

[5] Jacquin, N.J. (1760) Enumeratio Systematica Plantarum quas in insulis Caribaeis. Inter Documentation Company AG, Leiden, pp. 28

[6] Jansen, R. K. (1981). Systematics of Spilanthes (Compositae: Heliantheae). Systematic Botany, 231-257

[7] Jansen, R. K. (1985). The systematics of Acmella (Asteraceae-Heliantheae). Systematic Botany Monographs, 1-115.

[8] Moore, A. H. (1907). Revision of the genus Spilanthes. Contributions from the Gray Herbarium of Harvard University, 521-569.

[9] Reshmi, G. R., \& Rajalakshmi, R. (2016). Three new combinations in Acmella (Asteraceae: Heliantheae). Trop Plant Res Int J, 3(1), 67-69.

[10] Richard, L. C. (1807) Acmella. In: Persoon C (ed) Synopsis Plantarum, Paris, 42: pp. 472-473.

[11] Bhole, P. V. \& Pathak, J. M. (1988). Flora of Saurashtra, Part-II. Botanical survey of India, Calcutta, pp. 34.

[12] Shah G. L. (1978). Flora of Gujarat. Sardar Patel Univrsity. Vallabh vidhyanagar. 